\title{
Performance and Biological Implications of a Multi-gear Fishery for Greenland Halibut (Reinhardtius hippoglossoides)
}

\author{
Kjell H. Nedreaas, Aud Vold Soldal and Åsmund Bjordal \\ Institute of Marine Research, Department of Marine Resources, P.O.Box 1870 Nordnes, \\ N-5024 Bergen, Norway
}

\begin{abstract}
Simultaneous full-scale fishing operations using bottom trawl, gillnet and longline for Greenland halibut (Reinhardtius hippoglossoides, Walbaum) were performed in the Barents Sea (ICES Divisions IIa and IIb) for two weeks in October 1992. The mesh size of the trawl codend was $135 \mathrm{~mm}$, and that of the gillnets $220 \mathrm{~mm}$. Additionally, seven gillnet fleets of $180 \mathrm{~mm}$ mesh size were set for selectivity comparison. The catch rates and the length distributions of the Greenland halibut in the catches taken by trawl, longline and gillnet were different. Gillnets almost exclusively caught fish between 60 and $70 \mathrm{~cm}$, mostly mature females (about 90\%). The size distribution taken by longline was wider than that taken by gillnet. Two thirds of the longline catches were females, and the proportion of immature individuals was larger (14-30\%) than in the gillnet catches. The trawls, however, caught large amounts of fish between 40 and $60 \mathrm{~cm}$, consisting of almost equal amounts of males and females, and $30-40 \%$ immature fish. Gear-specific selection properties were the main reasons for the observed differences.
\end{abstract}

Yield-per-recruit and spawning-stock-biomass-per-recruit analyses showed that fixed gears captured proportionally fewer immature fish, and thus indicated they would provide greater spawning biomass and yield-per-recruit than would trawl gear, for an equivalent reference fishing mortality rate.

Key words: Barents Sea, distribution, fishing gear, gear selectivity, Greenland halibut

\section{Introduction}

Strict regulation of the Greenland halibut (Reinhardtius hippoglossoides, Walbaum) fishery in ICES Subareas I and II was introduced in 1992 to rebuild the depleted North-East Arctic stock. In order to continue an established series of commercial trawl catch-per-unit-effort (CPUE) data, and to improve biological sampling as a basis for stock assessment, fishing vessels were contracted for commercial-scale fishing, although restricted to certain time periods and areas. The gears used by the different vessels were trawls, longlines and gillnets.

The present study compares the performance of the different gears and their biological implications for fishery management. The growth rates of male and female Greenland halibut are different, and fish larger than $70 \mathrm{~cm}$ and heavier than $4 \mathrm{kgs}$ are almost exclusively females (Bowering, 1983, Kovtsova and Nizovtsev, MS 1985). Male Greenland halibut also reach sexual maturity at younger ages and smaller sizes than females. Godø and Haug (1987) have documented size-related geographic and depth distributions for the species. Optimal stock management therefore depends on regulations taking these facts into consideration.

Due to different selection properties it is expected that different fishing gears will harvest different parts of the stock with regard to length, age and sex composition. The present study allowed simultaneous comparisons between trawl, gillnet and longline gear during a full-scale fishing operation.

\section{Materials and Methods}

Commercial fishing vessels were contracted to conduct regular fishing operations in order to obtain information on how the fishery for Greenland halibut is conducted (e.g. to evaluate the quality of catchper-unit-effort data as a measure of the fishable stock size) and to obtain sufficient biological data to assess the stock.

One freezer trawler (45.4 m LOA, $1500 \mathrm{HP}$, later called Trawl 1), one factory trawler (56.9 m LOA, $3300 \mathrm{HP}$, later called Trawl 2) and one longliner (37.7 m LOA, $1075 \mathrm{HP}$ ) were contracted to fish for 
Greenland halibut on the traditional fishing grounds for 16 fishing days from 5 to 21 October 1992. In addition, a gillnet vessel (37.5 m LOA, $750 \mathrm{HP}$ ) was contracted for 12 fishing days in the same period. Fishing was conducted in the official Norwegian Statistical Areas 12 and 39 in ICES Division Ila between $71^{\circ} 30^{\prime} \mathrm{N}$ and $73^{\circ} 30^{\prime} \mathrm{N}$, and Areas 20 and 27 in ICES Division IIb which extends from $73^{\circ} 30^{\prime} \mathrm{N}$ to $76^{\circ} \mathrm{N}$ (Fig. 1). The vessels were to spend the same amount of time in each of the Areas, apart from Area 27, in which the trawlers were only allowed to fish for one day.

The trawlers used standard cod bottom-trawls. The factory trawler alternated between two '135 mm' (inside stretched mesh, measured to 137.7 and $139.4 \mathrm{~mm}$ on average) 'Alfredo 5' trawls with twin cod-ends. The vertical trawl opening was about 4 $\mathrm{m}$ and the distance between the doors averaged

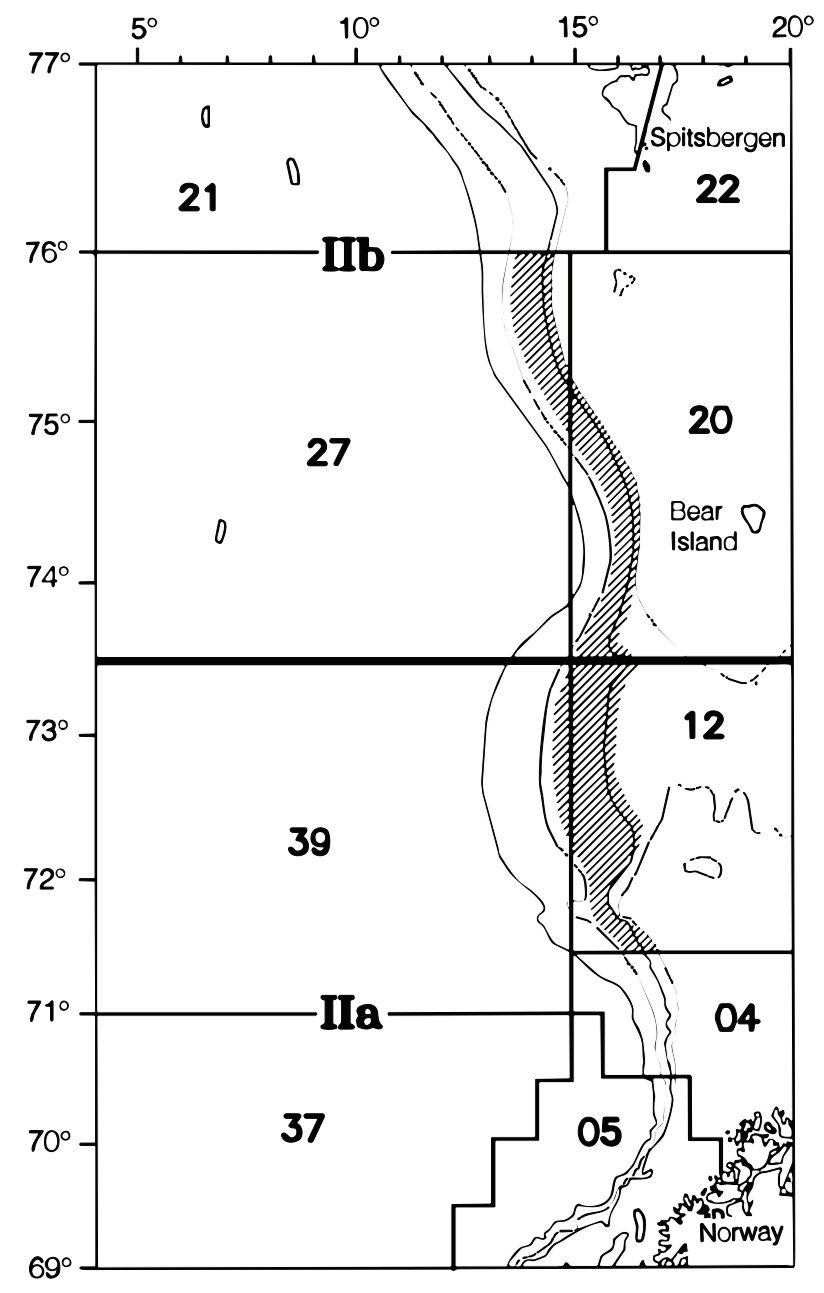

Fig. 1. Experimental area (shaded) in the ICES Divisions IIa and IIb. Further divisions are official Norwegian statistical areas. Depth contours have been drawn for 400, 500, 1000 and $1500 \mathrm{~m}$.
170-175 m. One of the trawls was equipped with bobbin gear, the other with rock-hopper gear. French Malo-doors (type R PS15E, $2700 \mathrm{~kg}$ ) were used. The freezer trawler used two '135 mm' (measured to 137.5 and $139.6 \mathrm{~mm}$ on average) 'Alfredo 3' trawls with twin cod-ends and a lighter ground gear than the factory trawler. The trawl geometry was not measured. Both trawls were equipped with rock-hopper gear. Malo-doors were also used on this vessel (type R PS13, $2000 \mathrm{~kg}$ ). The lengths of the ground gears were $106.7 \mathrm{~m}$ and $80.3 \mathrm{~m}$ on the factory trawler and freezer trawler, respectively. The sweep lengths used by the factory and the freezer trawlers were $128 \mathrm{~m}$ and $136.5 \mathrm{~m}$, respectively, and the warp length during towing was 2.5-2.8 times the bottom depth, dependent on current and bottom condition. Towing speed was 4 knots (2 m/sec), and towing duration usually 4-5 hours. Sixty-two hauls were taken by the freezer trawler (trawl 1) and 77 hauls by the factory trawler (trawl 2). For statistical analyses each haul was treated separately.

The longliner used $7 \mathrm{~mm}$ diameter swivel longline with Mustad EZ-baiter hooks no. 12/0 with a hook spacing of $1.4 \mathrm{~m}$. Each longline fleet consisted of 5400 hooks. The hooks were baited mechanically (Mustad Autoline System) with sequences of squid, mackerel or herring, in total with approximately equal amounts of each bait type. Average bait width was $28 \mathrm{~mm}$. The soak time varied between 6 and 24 hours. A total of 85 longline fleets were hauled. Each fleet of gear was treated as one unit (called 'station') in the statistical calculations.

The gillnets were made of monofilament with a mesh size of $220 \mathrm{~mm}$ (distance from center of one knot to the center of the opposite knot of a stretched mesh). Thirty nets, each $30 \mathrm{~m}$ long, were tied endto-end to a fleet. A further seven fleets of $180 \mathrm{~mm}$ nets were set during the experiments to compare selectivity. The height of the nets were 20 meshes, and the hanging ratio $60 \%$. The float and lead lines were of $14 \mathrm{~mm}$ diameter. A total of 120 fleets were hauled, with a daily variation of six to 16 fleets. One fleet was treated as one unit ('station') in the statistical calculations. The gillnet fleets were bottom-set, anchored to the bottom at one end only, letting the other end drift freely with the current. The gillnet soak time varied from 50 to 140 hours, with an average of 87 hours.

The mean lengths of fish in each trawl haul or gillnet/longline fleet and the $90 \%$ length range $\left(L_{95 \%}-L_{5 \%}\right)$ were fitted to a general linear model (GLM, SAS Institute) to evaluate the effect of fishing depth, geographical area and fishing gear on the size distribution of Greenland halibut in the catches. Only hauls/fleets in statistical areas and at depths 
where the different gears (Trawl 2, Iongline and gillnet) fished simultaneously (i.e. areas 12, 20, and 39, and depths between 520 and $600 \mathrm{~m}$ ) were included in the analysis. Trawl 1 did not fish within this depth range, only 7 hauls were conducted by Trawl 2 , while 20 longlines (at depths between 520 and $560 \mathrm{~m}$ ) and 69 gillnet fleets were set. The model used was:

$$
y_{i j}=u+g_{i}+a_{j}+k d+\varepsilon
$$

where $y_{i j}$ is the mean fish length or the $90 \%$ length interval for each gear $\mathrm{i}$ and area $\mathrm{j}$,

$u$ is the intercept,

$g_{i}$ is the effect of the fishing gear $i$,

$a_{j}$ is the area j effect and $k d$ is the depth effect, and

$\varepsilon$ represents the random variation or error.
As none of the interaction effects turned out to be significant, they were omitted from further discussion in the text.

Table 1 shows the input parameters for yieldper-recruit ( $Y / R)$ and spawning-stock-biomass-perrecruit $(S S B / R)$. The exploitation patterns were estimated by taking the average catch-in-numbersat-age for each gear from four years (1992-95) of experimental fishery and dividing it by a long-term stock number-at-age (years 1980-85 in Anon., MS 1996). An historic time series (1980-85) of stock numbers was considered to be the most appropriate, since the stock numbers-at-age in recent years are influenced by the recruitment failure which has not yet shown up in the experimental fishery. Ages 4-14 (no plus-group) were included in these analyses.

TABLE 1. Input parameters for yield-per-recruit (Y/R) and spawning-stock-biomass-per-recruit (SSB/R). Exploitation patterns and individual weights for each gear have been taken as the average from the experimental fishery in 1992-95. Natural mortality and maturity ogive (average 1991-93) are taken from the Arctic Fisheries Working Group (Anon., MS 1995). Individual weights in the stock have been set equal to the weights in the trawl catch.

\begin{tabular}{|c|c|c|c|c|c|c|}
\hline \multirow[b]{2}{*}{ Age } & \multicolumn{2}{|c|}{ Trawl } & \multicolumn{2}{|c|}{ Longline } & \multicolumn{2}{|c|}{ Gillnet } \\
\hline & $\begin{array}{l}\text { Exploitation } \\
\text { pattern }\end{array}$ & $\begin{array}{l}\text { Weight in } \\
\text { catch }(\mathrm{kg})\end{array}$ & $\begin{array}{c}\text { Exploitation } \\
\text { pattern }\end{array}$ & $\begin{array}{l}\text { Weight in } \\
\text { catch }(\mathrm{kg})\end{array}$ & $\begin{array}{l}\text { Exploitation } \\
\text { pattern }\end{array}$ & $\begin{array}{l}\text { Weight in } \\
\text { catch }(\mathrm{kg})\end{array}$ \\
\hline 3 & 0.01 & 0.26 & 0.00 & 0.26 & 0.00 & 0.26 \\
\hline 4 & 0.10 & 0.52 & 0.00 & 0.52 & 0.00 & 0.52 \\
\hline 5 & 0.81 & 0.73 & 0.03 & 0.78 & 0.00 & 0.78 \\
\hline 6 & 0.96 & 0.96 & 0.07 & 0.96 & 0.00 & 0.96 \\
\hline 7 & 1.64 & 1.30 & 0.38 & 1.31 & 0.02 & 1.34 \\
\hline 8 & 0.99 & 1.80 & 0.40 & 1.81 & 0.06 & 1.82 \\
\hline 9 & 1.03 & 2.17 & 1.18 & 2.12 & 0.75 & 2.12 \\
\hline 10 & 1.15 & 2.55 & 1.70 & 2.61 & 1.60 & 2.62 \\
\hline 11 & 0.72 & 3.30 & 1.29 & 3.35 & 2.49 & 3.34 \\
\hline 12 & 0.47 & 4.13 & 1.05 & 4.14 & 1.09 & 4.17 \\
\hline 13 & 0.21 & 4.88 & 0.35 & 4.98 & 0.33 & 4.97 \\
\hline 14 & 0.20 & 6.24 & 0.30 & 6.29 & 0.15 & 6.02 \\
\hline
\end{tabular}

\begin{tabular}{|c|c|c|c|c|c|c|}
\hline Age & $\begin{array}{l}\text { Recruitment } \\
\text { (numbers) }\end{array}$ & $\begin{array}{l}\text { Natural } \\
\text { mortality }\end{array}$ & $\begin{array}{l}\text { Maturity } \\
\text { ogive }\end{array}$ & $\begin{array}{l}\text { Prop. of F } \\
\text { before spawn }\end{array}$ & $\begin{array}{l}\text { Prop. of M } \\
\text { before spawn }\end{array}$ & $\begin{array}{l}\text { Weight in } \\
\text { stock }(\mathrm{kg})\end{array}$ \\
\hline 3 & 1.00 & 0.15 & 0.000 & 0.00 & 0.00 & 0.26 \\
\hline 4 & - & 0.15 & 0.033 & 0.00 & 0.00 & 0.52 \\
\hline 5 & - & 0.15 & 0.247 & 0.00 & 0.00 & 0.73 \\
\hline 6 & - & 0.15 & 0.550 & 0.00 & 0.00 & 0.96 \\
\hline 7 & - & 0.15 & 0.677 & 0.00 & 0.00 & 1.30 \\
\hline 8 & - & 0.15 & 0.717 & 0.00 & 0.00 & 1.80 \\
\hline 9 & - & 0.15 & 0.763 & 0.00 & 0.00 & 2.17 \\
\hline 10 & - & 0.15 & 0.890 & 0.00 & 0.00 & 2.55 \\
\hline 11 & - & 0.15 & 0.937 & 0.00 & 0.00 & 3.30 \\
\hline 12 & - & 0.15 & 0.987 & 0.00 & 0.00 & 4.13 \\
\hline 13 & - & 0.15 & 1.000 & 0.00 & 0.00 & 4.88 \\
\hline 14 & - & 0.15 & 1.000 & 0.00 & 0.00 & 6.24 \\
\hline
\end{tabular}




\section{Results}

The length-distributions and mean length of Greenland halibut in the longline, gillnet and trawl catches were very different (Fig. 2 and Table 2). The gillnets caught fish almost exclusively between 60 and $70 \mathrm{~cm}$, with a maximum at $65 \mathrm{~cm}$, while the length distribution of the longline catches was wider and bimodal with maxima at 52 and $64 \mathrm{~cm}$. The length-distributions of Greenland halibut taken by the two trawlers were almost identical, and even wider than that taken by longline, with a maximum between 45 and $52 \mathrm{~cm}$. The $50 \%$ retention length for Greenland halibut in a $135 \mathrm{~mm}$ trawl has been found to be $43 \mathrm{~cm}$ (Nedreaas, MS 1991), which fits well with the lower slope of the trawl lengthdistribution curve in Fig. 2.

The catch rates of the trawlers, particularly the factory trawlers, were much higher than that of the gillnet and longline vessels (Fig. 3 and Table 2). In spite of the higher proportion of large fish in the gillnet and longline catches, the total number of fish larger than $60 \mathrm{~cm}$ was higher for trawler than for longline, and only slightly less than in the gillnet catches. However, fish smaller than $60 \mathrm{~cm}$ were almost exclusively taken by trawler ( $96 \%$ of total catch).
Although fishing was restricted to certain statistical areas, the skippers had little restrictions in choosing their fishing positions within the main areas. As can be seen in Fig. 4, the trawlers fished deeper (520-750 $\mathrm{m}$ depth) than the gillnet vessel (450-600 $\mathrm{m}$ depth) and the longliner (400-560 m). The freezer trawler (Trawl 1) did not have a single haul in the depths fished by longline and gillnet, while Trawl 2 made a limited number of hauls between 500 and $600 \mathrm{~m}$ depth for gear comparisons.

To evaluate the effects of fishing depth, fishing area and gear on the mean fish length and 90\% length interval of the catches, hauls/fleets taken between 520 and $600 \mathrm{~m}$ depth (longlines only between 520 and $560 \mathrm{~m}$ ) were selected for GLM analyses (Tables 3 and 4 ). Within this rather limited depth range, there was no significant effect of depth on the mean fish length ( $p=0.640$ ), while the $90 \%$ length range $\left(L_{95 \%}-L_{5 \%}\right)$ seemed to be somewhat influenced by depth $(p=0.020)$. The gear type and fishing area both had a significant effect on the mean fish length $(p<0.001)$, while only area seemed to have an effect on the length range $(p=0.022$ for area effect and $p=0.881$ for gear effect).

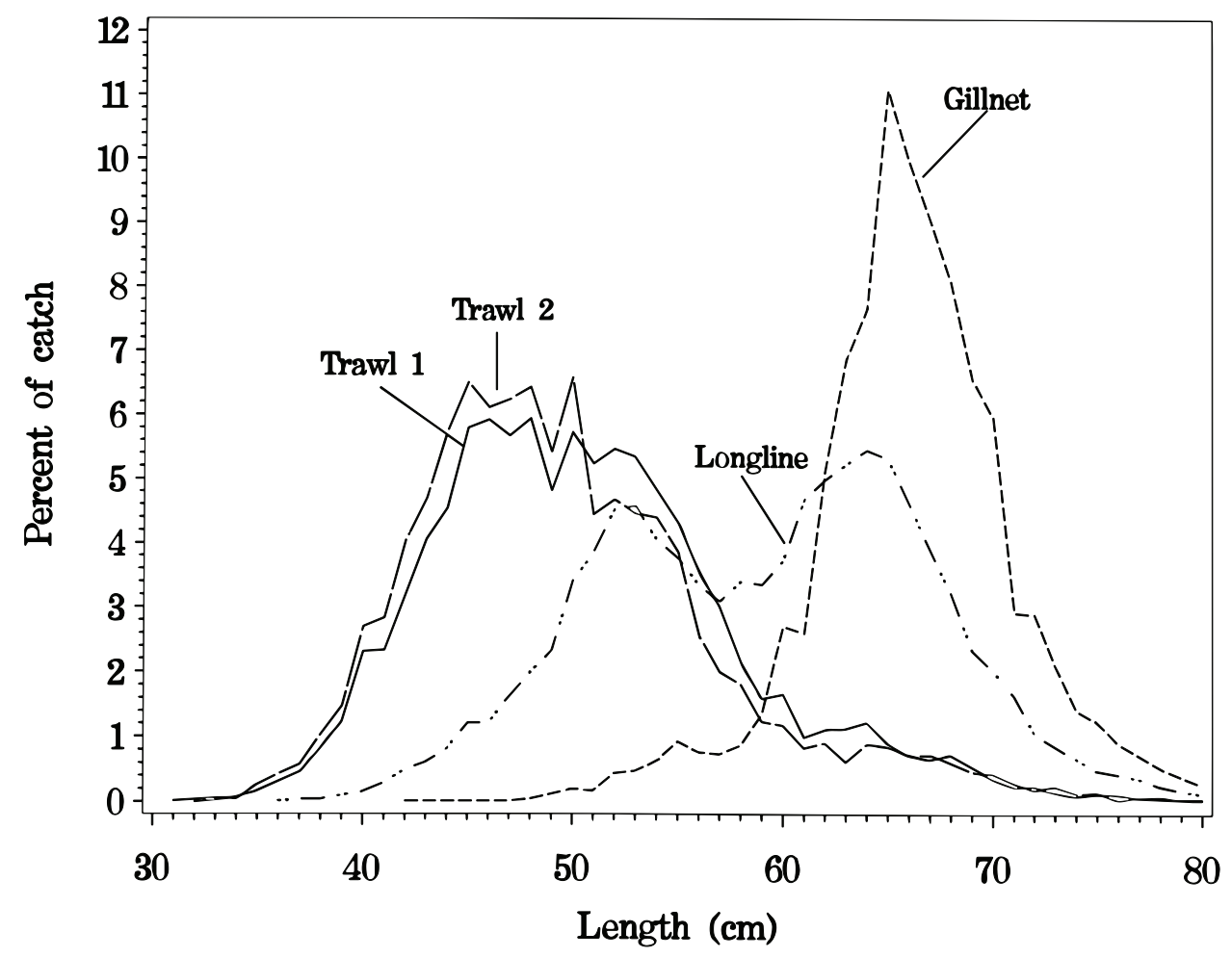

Fig. 2. Length-distributions of Greenland halibut caught by freezer trawler (Trawl 1), factory trawler (Trawl 2), longline and gillnets. 


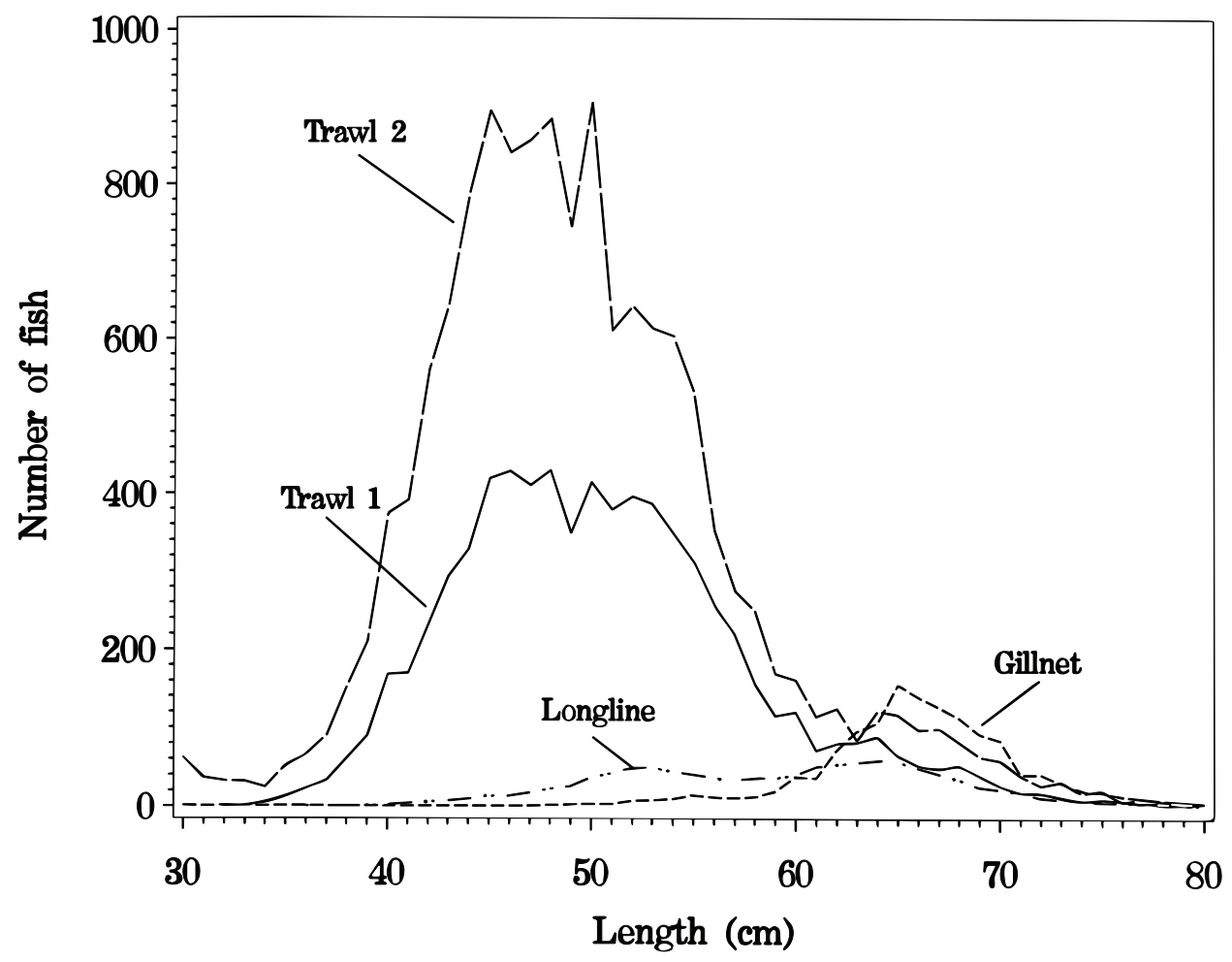

Fig. 3. Average number of Greenland halibut taken per fishing day by trawls, Iongline and gillnets.

The length-weight and length-age relationships are given in Fig. 5 and 6, while the age compositions of the catches of different gears are shown in Fig. 7. Gillnet catches consisted mainly of fish older than 6 years, while the trawl catches consisted of a broader age range, from 3 to 12 years. Lack of 9 year old Greenland halibut can to some extent be explained by relatively fewer fish of about $60 \mathrm{~cm}$ length (Fig. 2 and 3 ). However, more recent comparisons of age- and length-distributions have shown that this effect is rather caused by an age reading problem.

About $50 \%$ of the North-East Arctic Greenland halibut, both sexes combined, mature at an age of 6 to 7 years (Kovtsova and Nizovtsev, MS 1985, Anon., MS 1996), males earlier than females. At age 4 to $5(40-43 \mathrm{~cm})$ about $50 \%$ of the males are mature, while not until age 9 (about $60 \mathrm{~cm}$ ) do $50 \%$ of the females become mature (Kovtsova and Nizovtsev, MS 1985). Thus the fractions of mature fish are larger in the gillnet and longline catches than in the trawl catches (Table 5).

The growth potential of Greenland halibut differs only slightly between the sexes. From an age of about 5 (approximately $42-43 \mathrm{~cm}$ ) the growth of females slightly exceeds that of males (LahnJohannessen, MS 1972; Kovtsova and Nizovtsev, MS 1985), but the mortality must be different since only a few males larger than $65 \mathrm{~cm}$ are encountered. As a result of this, the sex composition of the catches varied between the gears. Thus, the trawlers caught almost equal proportions of males and females, while the proportions of males were one third and one tenth in the longline and gillnet catches, respectively (Table 6).

In order to quantify an increase in yield and spawning stock biomass that can be derived from changes in gear effort, Y/R and SSB/R were estimated (Fig. 8). Gillnet gives the highest and trawl the lowest $Y / R$ irrespective of fishing mortality. The fishing mortality $\left(F_{7-12}\right)$ giving maximum $Y / R$ is 0.37 for trawl, 0.57 for longline, and 0.71 for gillnet. Gillnet and longline give $15-30 \%$ higher $\mathrm{Y} / \mathrm{R}$ than trawl dependent on gear and fishing mortality. Fig. 8 shows a difference in $Y / R$ of $150-200$ grams corresponding to a yearly quota difference of 4000 5000 tons assuming an average recruitment of 27 million specimens at age 3 . The gear effect is more pronounced when looking at SSB/R. Using trawl alone would result in 40-50 000 tons less SSB on the long term assuming constant average recruitment. 


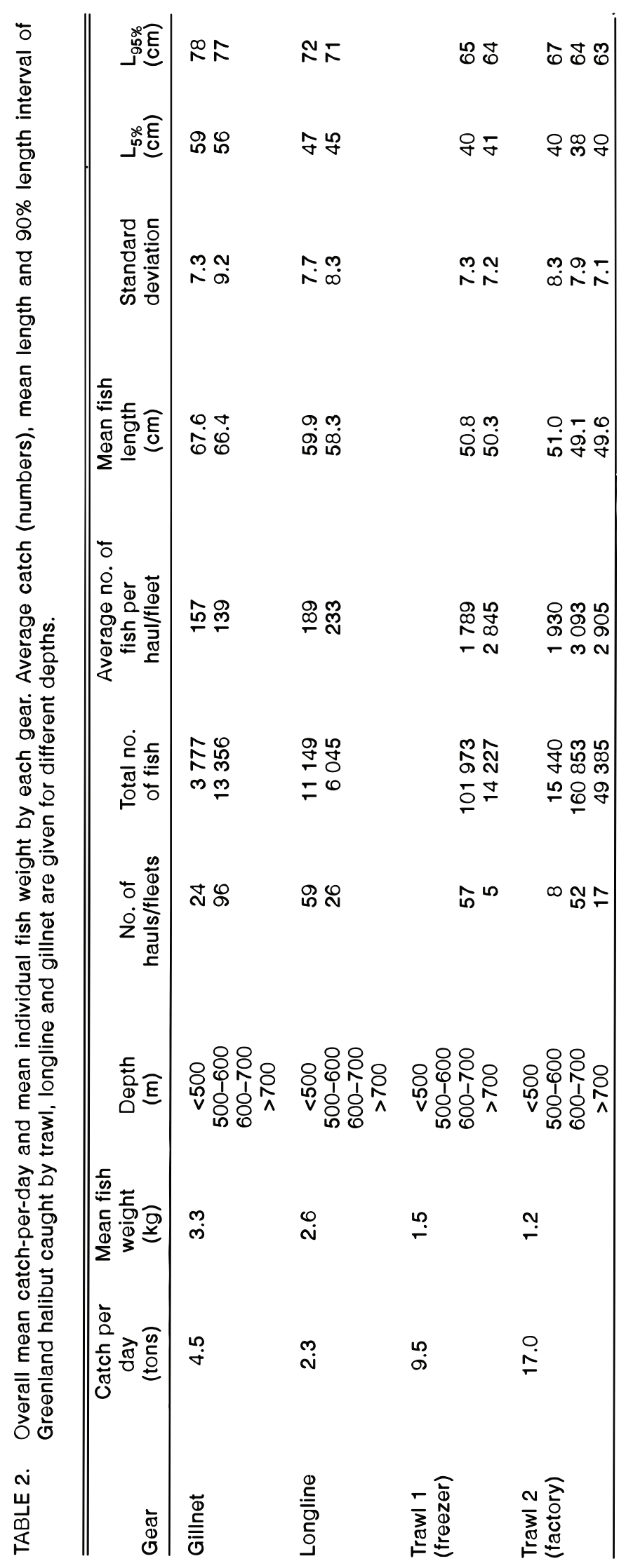




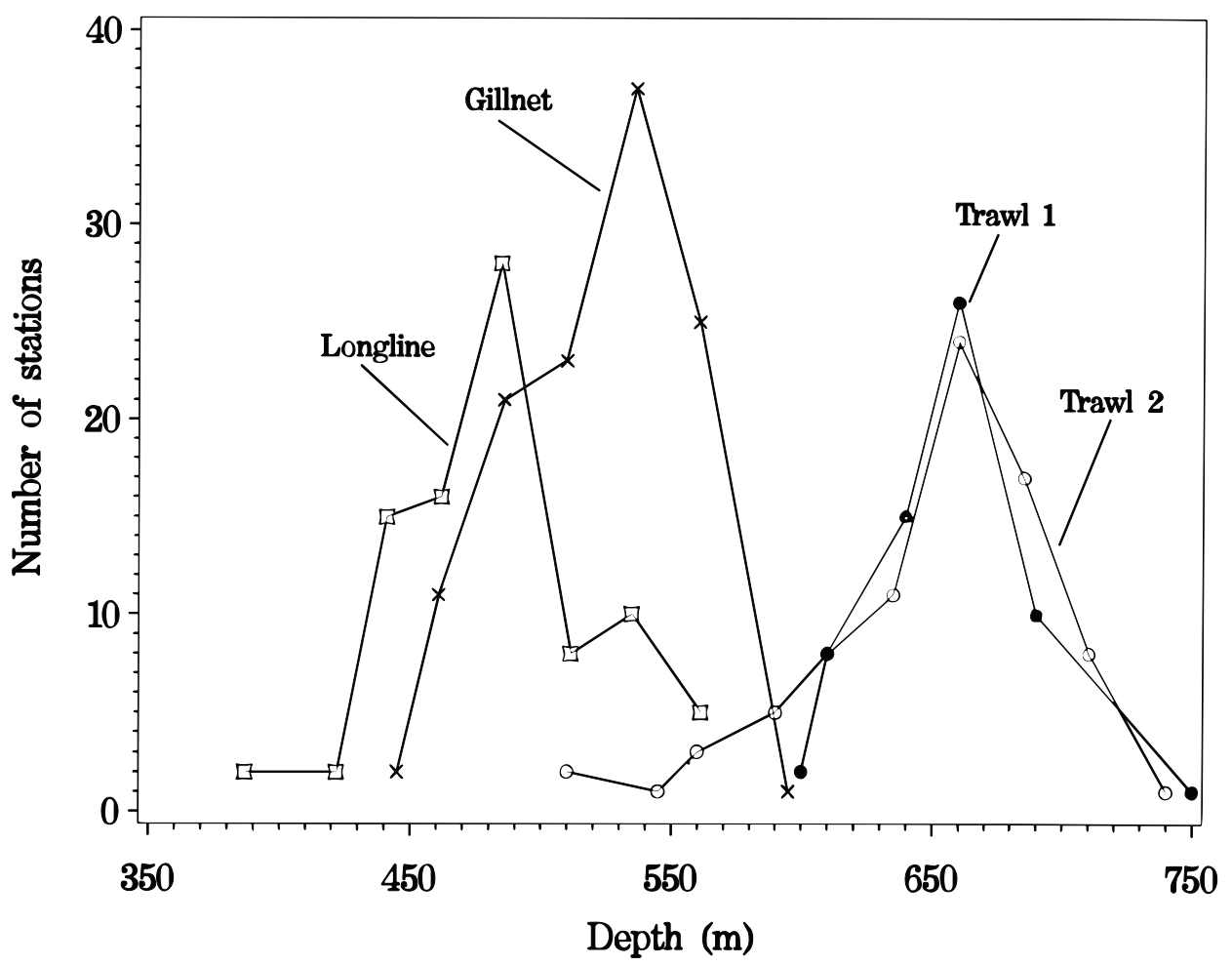

Fig. 4. Number of fishing stations taken by trawls, longline and gillnets at different fishing depths during the experiments.

TABLE 3. General linear model (GLM, SAS Institute) of the effect of fishing gear, fishing area and fishing depth on the mean Greenland halibut length in the catches.

\begin{tabular}{lcrrrr}
\hline \hline $\begin{array}{c}\text { Source of } \\
\text { variation }\end{array}$ & $\begin{array}{c}\text { Degrees of } \\
\text { freedom }\end{array}$ & $\begin{array}{c}\text { Sum of } \\
\text { squares }\end{array}$ & $\begin{array}{c}\text { Average sum } \\
\text { of squares }\end{array}$ & F & $\begin{array}{c}\text { Significance } \\
\text { level }\end{array}$ \\
\hline $\begin{array}{l}\text { Main effects } \\
\text { Gear }\end{array}$ & 2 & 218828 & 109414 & 167.59 & $<0.001$ \\
$\quad \begin{array}{l}\text { Area } \\
\text { Depth }\end{array}$ & 2 & 11177 & 5589 & 8.56 & $<0.001$ \\
Residual & 1 & 143 & 143200 & 0.22 & \\
Total & 90 & 58757 & 653 & & \\
\hline
\end{tabular}

TABLE 4. General linear model (GLM, SAS Institute) of the effect of fishing gear, fishing area and fishing depth on the $90 \%$ interval $\left(L_{95}-L_{5 \%}\right)$ of Greenland halibut length in the catches.

\begin{tabular}{|c|c|c|c|c|c|}
\hline $\begin{array}{l}\text { Source of } \\
\text { variation }\end{array}$ & $\begin{array}{l}\text { Degrees of } \\
\text { freedom }\end{array}$ & $\begin{array}{l}\text { Sum of } \\
\text { squares }\end{array}$ & $\begin{array}{c}\text { Average sum } \\
\text { of squares }\end{array}$ & $\mathrm{F}$ & $\begin{array}{c}\text { Significance } \\
\text { level }\end{array}$ \\
\hline \multicolumn{6}{|l|}{ Main effects } \\
\hline Gear & 2 & 5272 & 2636 & 0.13 & 0.881 \\
\hline Area & 2 & 165605 & 82802 & 4.00 & 0.022 \\
\hline Depth & 1 & 117044 & 117044 & 5.65 & 0.020 \\
\hline Residual & 90 & 1865027 & 20722 & & \\
\hline Total & 95 & 2152959 & & & \\
\hline
\end{tabular}



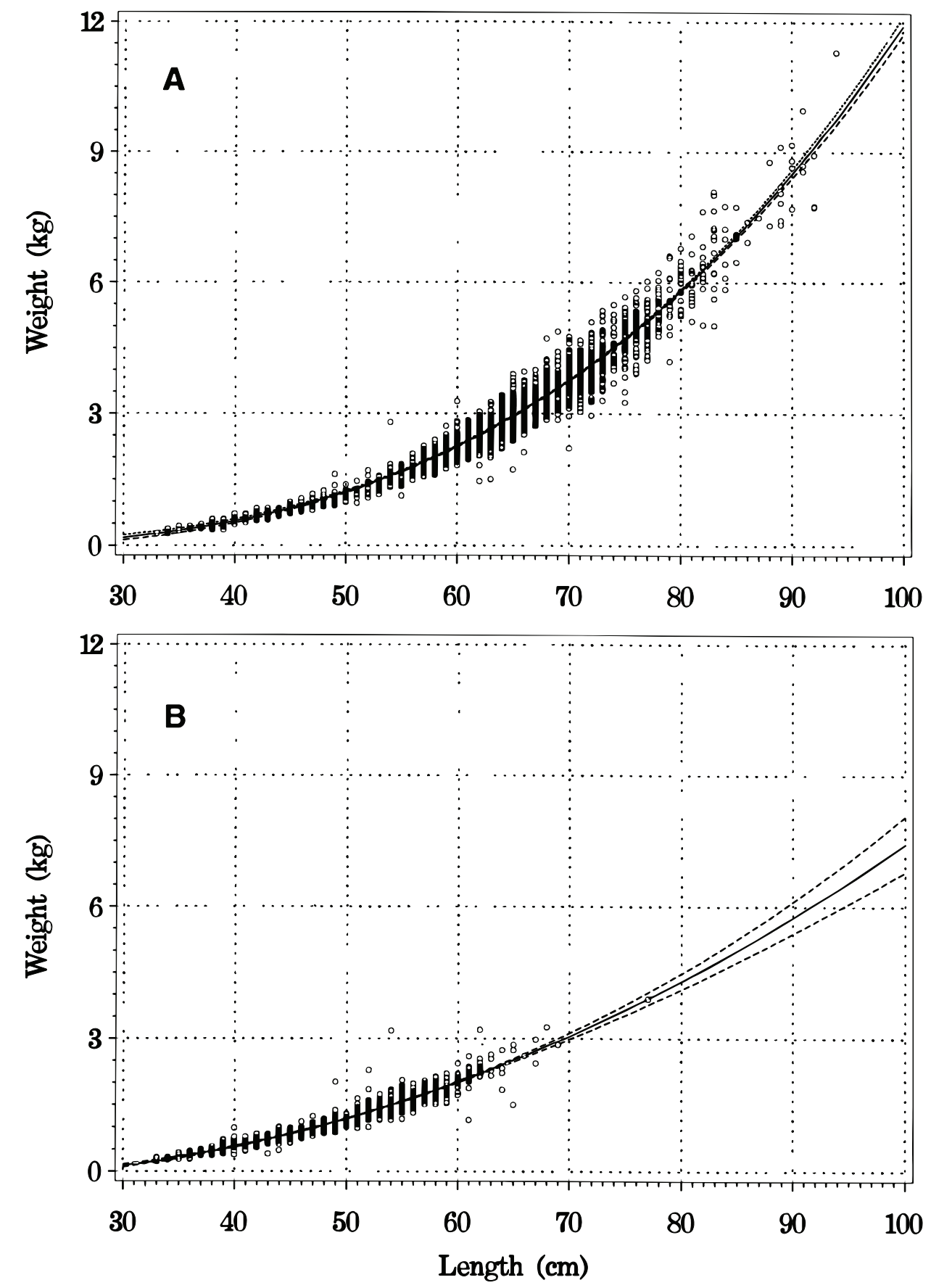

Fig. 5. Measured length/weight relationship for female (a) and male (b) Greenland halibut during the experiments. (Females: $W=0.267 L-0.229 L^{2}+0.014 L^{3}$; Males: $W=-$ $\left.23.98 L+0.923 L^{2}+0.001 L^{3}\right)$.

\section{Discussion}

Why was the size composition of Greenland halibut in trawl, longline and gillnet catches different?

The three gears targeted stock components with different size distributions: The three types of gear fished for the most part at different depths; the trawlers on average about $150 \mathrm{~m}$ deeper than the other two gears. If the size distribution of the Greenland halibut population changed with depth, this might explain the differences in size distribution. Godø and Haug (1987) found that adult Greenland halibut are most abundant in deeper 


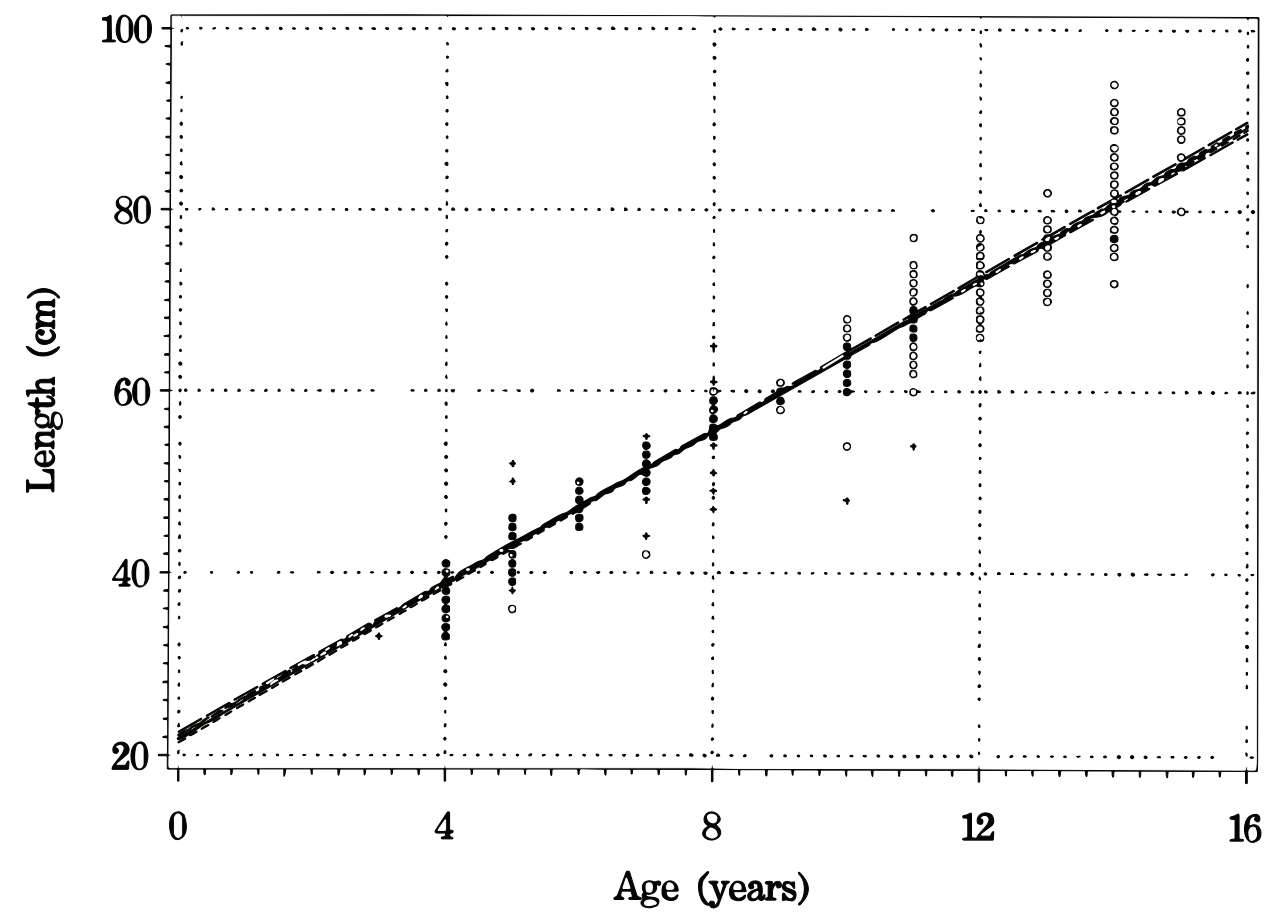

Fig. 6. Length/age relationship for female (circles) and male (+) Greenland halibut caught during the experiments. A linear regression curve is fitted to the data.

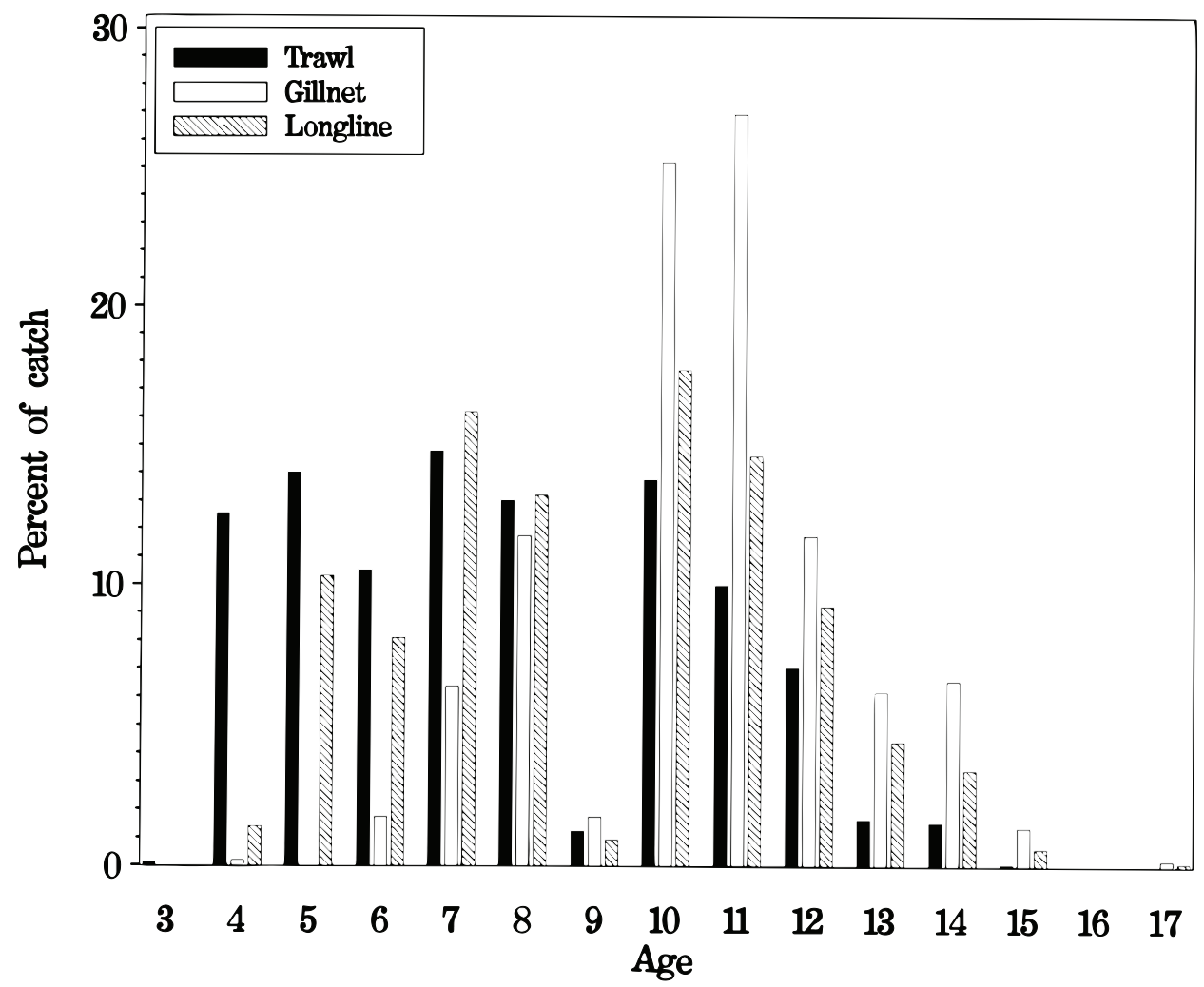

Fig. 7. The distribution of ages of Greenland halibut caught by trawls, longlines and gillnets during the experiments. Length was translated to age by an age-length key. 
TABLE 5. The observed proportion (percentages) of immature and mature male and female Greenland halibut in the trawl, longline and gillnet catches.

\begin{tabular}{llcccr}
\hline \hline Sex & Maturity & $\begin{array}{c}\text { Trawl 1 } \\
\text { (freezer) }\end{array}$ & $\begin{array}{c}\text { Trawl 2 } \\
\text { (factory) }\end{array}$ & $\begin{array}{c}\text { Gillnet } \\
(220 \mathrm{~mm})\end{array}$ & Longline \\
\hline Females & Immature & 43.0 & 41.2 & 0.3 & 31.5 \\
& Mature & 57.0 & 58.8 & 99.7 & 68.5 \\
Males & Immature & 25.7 & 37.2 & 0.0 & 13.7 \\
& Mature & 74.3 & 62.8 & 100.0 & 86.3 \\
\hline
\end{tabular}

TABLE 6. The sex distribution (percentages and numbers sampled) of Greenland halibut catches in trawl, longline and gillnet catches observed during the experiments.

\begin{tabular}{llcccr}
\hline \hline Sex & & $\begin{array}{c}\text { Trawl 1 } \\
\text { (freezer) }\end{array}$ & $\begin{array}{c}\text { Trawl 2 } \\
\text { (factory) }\end{array}$ & $\begin{array}{c}\text { Gillnet } \\
(220 \mathrm{~mm})\end{array}$ & Longline \\
\hline Females & Percent & 51.0 & 48.4 & 86.5 & 66.6 \\
& No. sampled & 515 & 458 & 383 & 663 \\
\multirow{3}{*}{ Males } & Percent & 49.0 & 51.6 & 13.5 & 33.4 \\
& No. sampled & 494 & 488 & 60 & 333 \\
\hline
\end{tabular}

water, but after having reached a certain size the depth distribution with regard to fish-length seems to change with season and area. At the time of the present study (October), Table 2 shows that within each gear category the mean fish length decreased slightly with increasing depth. The fact that the bigger mature fish were shallower is believed to be connected to spawning, which, judged from the maturity stage, would take place 1-2 months later. Other investigations in the spring have shown that the size of Greenland halibut at that time increase with depth (Nedreaas, unpublished or pers. comm.).

The number of trawl stations taken within the same depth interval as longline and gillnets, was limited. In fact, the freezer trawler did not make a single haul as shallow as the deepest longline and gillnet stations, while the factory trawler only conducted seven hauls in an overlapping depth range (520-600 $\mathrm{m}$ depth). The analysis to evaluate the effect of a possible difference in size distribution of Greenland halibut by depth and area was therefore based on a limited number of hauls, and the depth range where the three gears fished simultaneously was narrow. A non-significant effect of depth on the mean fish length was therefore not surprising. An analysis covering a greater depth range might have given another result since within each gear category the mean fish-length decreased by increasing depth. However, the mean fish length was significantly influenced by the fishing area and fishing gear. This indicates that there was a difference in horizontal size distribution of fish by area, and also, as was expected, that there are differences in the selective properties of the different fishing gears.

The gears had different selective properties: The selective properties of gillnets are well documented (e.g. Olsen, 1959; Hamley, 1975; Hylen and Jakobsen, 1979, Aldebert et al., 1993), and the narrow selection range of gillnets, which is mainly dependent on mesh size, is also reflected in the present investigation. Gillnet selection remains fairly constant regardless of the size composition of the fish in the area. The mesh size mostly used in these experiments $(220 \mathrm{~mm})$ had a distinct maximum at fish lengths of $65 \mathrm{~cm}$ (Fig. 9a). However, seven fleets consisting of $180 \mathrm{~mm}$ gillnets set during the experiments caught fish of a wider range of lengths (Fig. 9b). The wider range was probably due to entangling of larger fish (Olsen and Tjemsland, 1963).

The selective properties of longline gear depend on several factors such as feeding motivation and hooking ability in different groups of fish, and competition between species and size groups when approaching the bait (Fernø et al., 1986; Bertrand, 1988; Løkkeborg and Bjordal, 1992). The number of fish of different species and size groups caught by longline gear is, therefore, influenced by numerous factors (e.g. Bjordal, 1988). In this experiment, the longline caught less small fish than the trawls, although the difference was slightly reduced when the gears were fishing at 


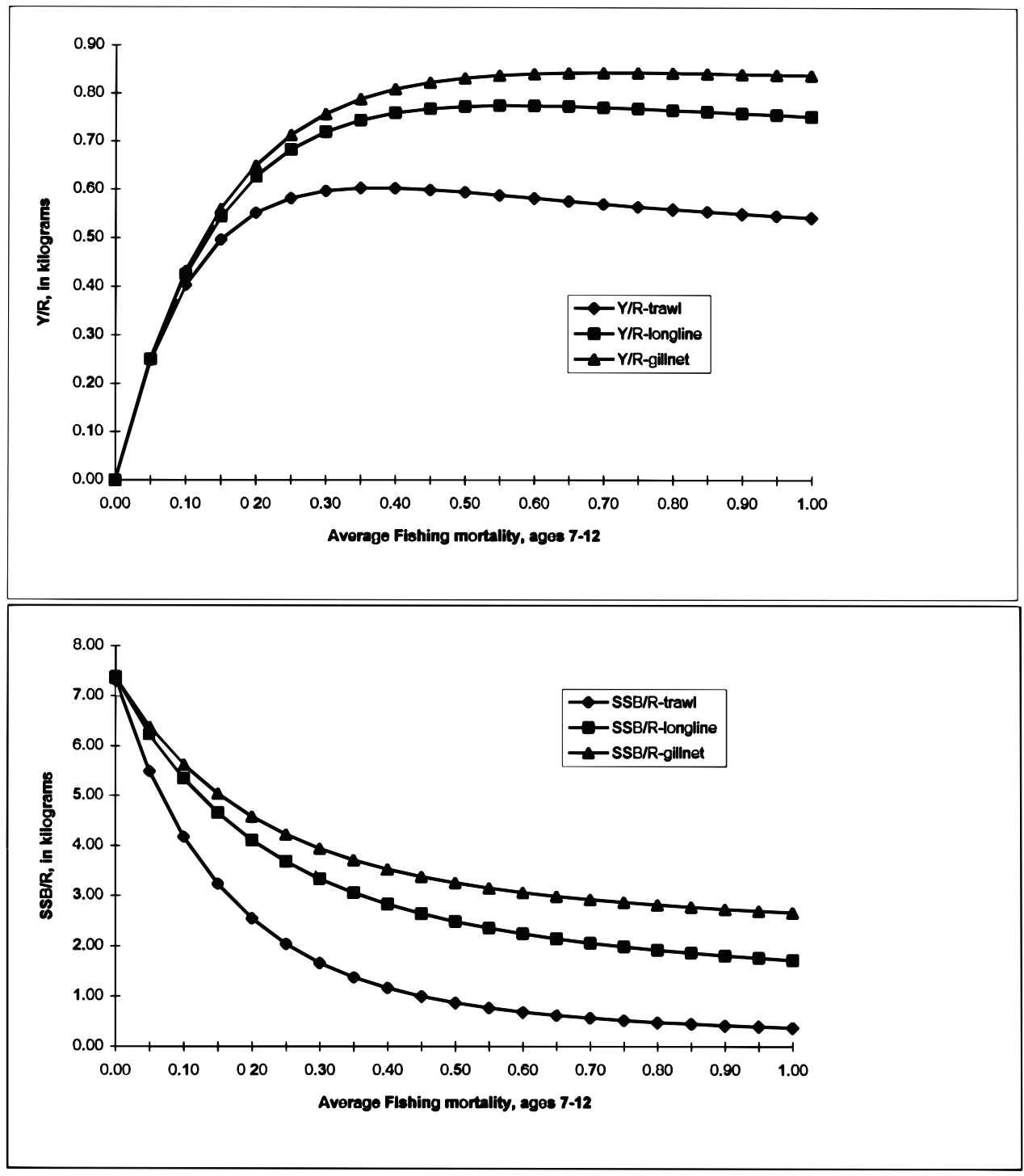

Fig. 8. Yield-per-recruit (Y/R) and spawning-stock-biomass-per-recruit (SSB/R) curves for $135 \mathrm{~mm}$ (codend, inner stretched mesh) trawl, longline and $220 \mathrm{~mm}$ (stretched mesh) gillnet in the fishery for North-East Arctic Greenland halibut.

similar depths. This may be due to fishing at stock components with slightly different size compositions, swimming range changing with size, and competition between fish of different sizes. If large Greenland halibut are able to swim for longer distances in search for food, or if the largest ones win the competition for bait, larger fish may be caught in relatively larger numbers than small ones. Thus the longline catches may not reflect the actual fish size distribution in the area (Løkkeborg and Bjordal, 1992; Engås et al., 1993). If there is a mixture of different fish-length groups in an area, the longline seem to catch the larger ones.
The trawl caught a much higher proportion of small Greenland halibut than other gears. Similar catch characteristics were reported in the fisheries for sablefish (Anoplopoma fimbria) off the American west coast (Klein, 1986), when landed catches taken by trawl, longline and set-nets were compared. The difference between gillnet and trawl is easily explained by the mesh selection properties of the gillnet. Unlike gillnet and Iongline, the trawl is an active gear, in principle harvesting all fish in the trawl path, if they are large enough to be held by the meshes in the cod-end. The trawl catches, therefore, better reflect the true size composition 

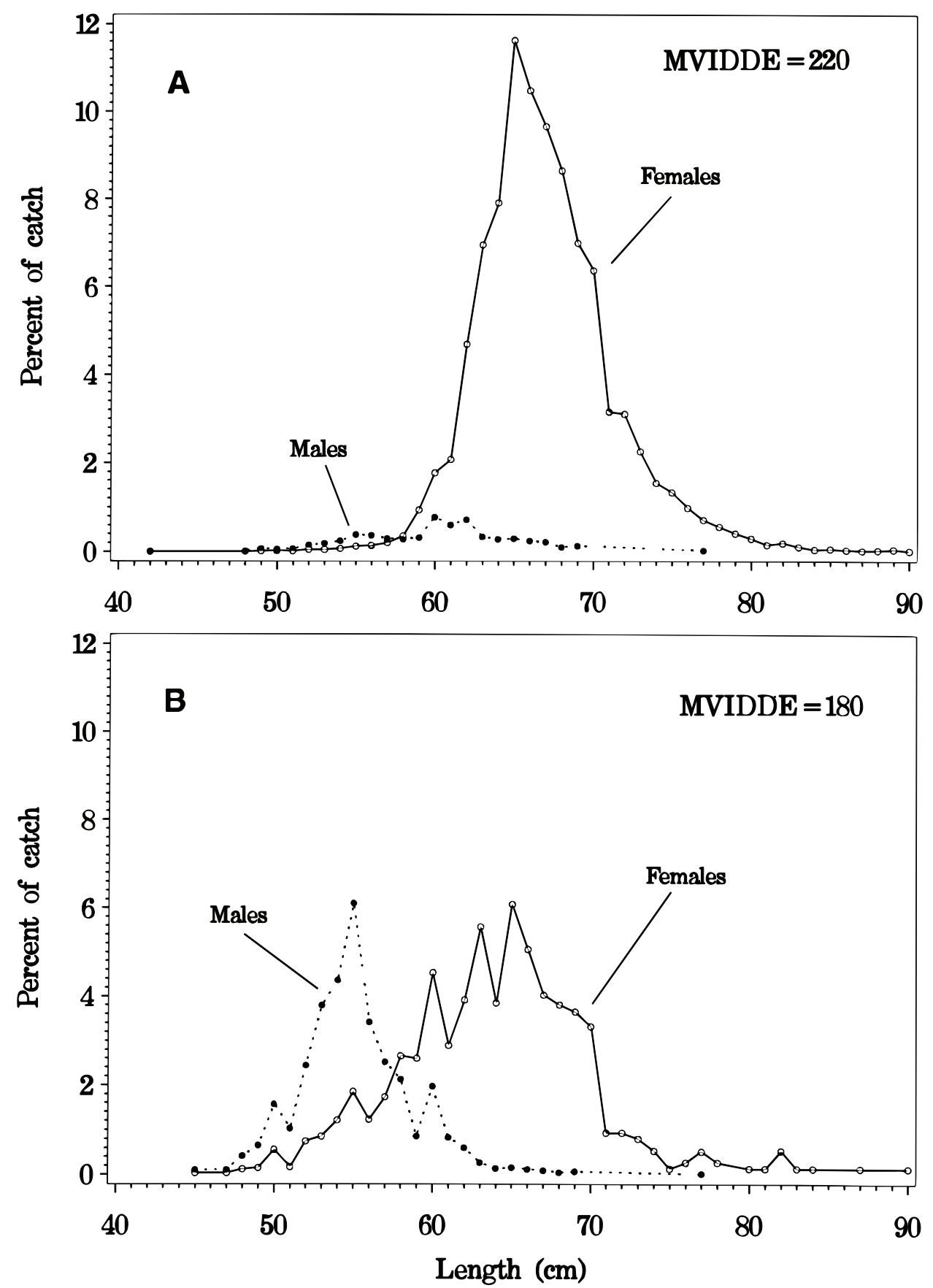

Fig. 9. Sex composition and length distribution of males and females caught by gillnets of $220 \mathrm{~mm}(\mathbf{A})$ and 180 (B) mesh size, respectively.

of Greenland halibut than the other gears. However, avoidance reactions to the approaching gear and fish escapement below the ground gear which may differ between age groups, are known to bias the length composition also in trawl catches (Engås and Godø, 1989; Ona and Godø, 1990).

Selection other than gear selection: The present investigation is one out of a few where the comparative selectivity of different fishing gears were studied during simultaneous full scale fishing. Beyond revealing significant differences in gear selectivity per se when the gears were fished in overlapping areas, the study clearly demonstrated the differences in total selection of the three fishing methods, i.e. the gear selection combined with the operational strategy of each gear. This strategy is how the skipper applies the gear to achieve the 
maximum catch rates, the largest fish or the best bottom ground, or rather, the optimal combination of these factors.

The bottom conditions were fairly similar throughout the entire fishing area, and should thus not be regarded as a restricting factor for any of the gears. Although the skippers were free to fish at any depths within the given areas, the trawlers obviously preferred to fish the deeper zones (Fig. 4 ), with only a few overlapping stations with the stationary gears, even if the skippers were encouraged to fish at overlapping depths.

When the fish size distribution changes with depth, as was the case in this study and is generally a common situation, applied fishing strategy do clearly affect the total selection of the fishing method. In the present case, with decreasing fish size with increasing depth, there is reason to believe that the operational strategy of the trawlers reinforced the pure gear selection towards smaller fish.

Total selection of the fishing method, rather than pure gear selection, should therefore be used for fisheries management purposes.

\section{Biological implications of the differences in selectivity}

To achieve an optimal harvesting strategy, the overall exploitation pattern may be altered by either changing the selection characteristics of the gears and/or by regulating the fishing mortality (effort) for each gear separately, in addition to keeping the overall fishing mortality at a biologically sound level.

The observed differences in CPUE and size composition of Greenland halibut in the catches taken by trawl, Iongline and gillnet, are certainly of importance in the choice of optimal harvesting strategy. The fishery for Greenland halibut in Norway has traditionally been carried out with longlines within restricted seasons and areas (ICES Areas I and IIa). In the late-1960s a trawl fishery and in the 1970s a gillnet fishery for Greenland halibut were developed (Godø and Haug, 1989).

To a great extent, the longline gear exploited the adult population from 6 years of age and upwards, both males and females, although there was a predominance of females in the catches (Table 6). The proportion of fish smaller than the current minimum legal catching size of $45 \mathrm{~cm}$ (within the Norwegian EEZ) was negligible, and the majority of fish were mature (Table 5). The size selectivity of longline may be altered to some extent by changing bait size, as the mean length of the fish taken in longline catches is shown to increase with increasing bait size (Bjordal, 1988; Løkkeborg, 1990). Therefore, longline gear seem to have the potential to take a more balanced harvest of Greenland halibut compared to the other two gears, at least with respect to size/age, although two thirds of the catch were females.

The gillnet catches were almost exclusively mature females older than 8 years. With a natural mortality of $\mathrm{M}=0.15$ (Anon., MS 1996), harvesting the Greenland halibut stock by gillnet of this mesh size will utilize the growth potential of the stock, but the female:male ratio of $87: 13$ can hardly be optimal. Gillnet fisheries could easily be targeted on other size groups by altering the mesh size, and gillnets of $180 \mathrm{~mm}$ mesh size not only caught fish of a smaller mean size and a wider length range (Fig. 9b), but also contained a higher proportion of males.

Since the late-1960s, trawling has been the major fishing method for Greenland halibut in the North-East Arctic. While longlines and gillnets exploit mature fish, trawls catch smaller fish and a large proportion of immature individuals. That trawls are less size selective than longlines has earlier been documented for cod (Gadus morhua) and haddock (Melanogrammus aeglefinus) (McCracken, 1963; Sætersdal, 1963; Hovgård and Riget, 1992), and for sablefish (Klein, 1986). The number of fish that a trawler can catch per day is far greater than that of longline or gillnet vessels of the types traditionally used in the Norwegian fisheries. This applies particularly to young females, which have not yet reached reproductive age.

The $Y / R$ analysis has shown that for a given fishing mortality the present trawl selection yields a $15-30 \%$ lower yield per recruit than gillnet and longline. Additionally, a lower price is normally obtained for the smaller fish (Nedreaas et al., MS 1995). The more serious negative biological effect of a trawl fishery with the current exploitation pattern (i.e., current mesh size) is shown by the SSB/R analysis. At the same fishing mortality the trawl fishery will, on the long term, keep the spawning stock biomass approximately 40-50 000 tons lower than the other gears, and a much smaller portion of the females will mature before being caught. However, a trawl fishery which exploits the resource at low fishing mortalities (e.g., $F_{7-12}$ less than 0.15 ) will maintain the spawning stock at higher levels than fishing at high rates (e.g., $F_{7-12}$ higher than 0.3 with longlines or 0.6 with gillnets) with fixed gears.

\section{Acknowledgements}

The authors thank the officers and crews of the fishing vessels 'Kongsfjord', 'Breistrand', 'Frøyliner' 
and 'Kato' for collecting valuable scientific information during their contracted fishing. We thank Anne Sæverud for reading the otoliths and preparing the data for further analysis. The paper has also greatly benefitted from two anonymous reviewers.

\section{References}

ALDEBERT, Y., L. RECASENS, and J. LLEONART. 1993. Analysis of gear interactions in a hake fishery: The case of the Gulf of Lions (NW Mediterranean). Sci. Mar., 57(2-3): 207-217.

ANON. MS 1995. Report of the Arctic Fisheries Working Group. Copenhagen, 23 Aug-1 Sept 1994. ICES C. M. Doc., No. Assess: 3, 252 p.

MS 1996. Report of the Arctic Fisheries Working Group. Copenhagen, 23-31 August 1995. ICES C. M. Doc., No. Assess: 4, $311 \mathrm{p}$

BERTRAND, J. 1988. Selectivity of hooks in the handline fishery of the Saya de Malha banks (Indian Ocean). Fish. Res., 6: 249-255.

BJORDAL, A. 1988. Recent developments in longline fishing - catching performance and conservation aspects. In: Proceedings of the World Symposium on Fishing Gear and Fishing Vessel Design, St. Johns, Newfoundland, Canada, Nov. 21-24, 1988: 19-24.

BOWERING, W. R. 1983. Age, growth and sexual maturity of Greenland halibut, Reinhardtius hippoglossoides (Walbaum), in the Canadian Northwest Atlantic. Fish. Bull. U.S., 81(3): 559-611.

ENGÅS. A, and O. R. GODØ. 1989. Escape of fish under the fishing line of a Norwegian sampling trawl and its influence on survey results. ICES J. Cons., 45: 269276.

ENGÅS, A., S. LØKKEBORG, E. ONA, and A. V. SOLDAL. 1993. Effects of seismic shooting on catch and catchavailability of cod and haddock. Fisken og Havet, 9, $117 \mathrm{p}$.

FERNØ, A., P. SOLEMDAL, and S. TILSETH. 1986. Field studies on the behaviour of whiting (Gadus merlangus) towards baited hooks. Fiskeridir. Skr. Havunders, 18: 83-95.

GODØ, O.R., and T. HAUG. 1987. Migration and recruitment to the commercial stock of Greenland halibut, Reinhardtius hippoglossoides (Walbaum), in the Svalbard area. Fiskeridir. Skr. Havunders, 18: 311-328.

1989. A review of the natural history, fisheries, and management of Greenland halibut (Reinhardtius hippoglossoides) in the eastern Norwegian and Barents Seas. ICES J. Cons., 46: 62-75.

HAMLEY, J. M. 1975. Review of gillnet selectivity. J. Fish.
Res. Board Can., 32: 1943-1969.

HOVGÅRD, H., and F. F. RIGET. 1992. Comparison of longline and trawl selectivity in cod surveys off West Greenland. Fish. Res., 13: 323-333.

HYLEN, A., and T. JAKOBSEN. 1979. A fishing experiment with multifilament, monofilament and monotwine gill nets in Lofoten during the spawning season of ArctoNorwegian cod. Fiskeridir. Skr. Havunders, 16(14): $531-550$

KLEIN, S. J. 1986. Selectivity of trawl, trap, Iongline and set-net gears to sablefish, Anoplopoma fimbria. NWAFC Processed Rep., 86-06, 84 pp.

KOVTSOVA, M. V., and G. P. NIZOVTSEV. MS 1985. Peculiarities of growth and maturation of Greenland halibut, of the Norwegian - Barents Sea stock in 1971-1984. ICES C. M. Doc., No. G:7(Sess. S), 17 p.

LAHN-JOHANNESSEN, J. MS 1972. Recent development of the fisheries of Greenland halibut (Reinhardtius hippoglossoides, Walbaum) in the Northeast Atlantic waters. ICES C. M. Doc., No. F:39, 8 p.

LØKKEBORG, S. 1990. Reduced catch of under-sized cod (Gadus morhua) in longlining by using artificial bait. Can. J. Fish. Aquat. Sci., 47: 1112-1115.

LØKKEBORG, S., and A. BJORDAL. 1992. Species and size selectivity in longline fishing: a review. Fish. Res., 13: 311-322.

McCRACKEN, F. D. 1963. Selection by codend meshes and hooks on cod, haddock, flatfish and redfish. In: The Selectivity of Fishing Gear. ICNAF Spec. Publ., 5: 131-155.

NEDREAAS, K. MS 1991. Minimum legal length of Greenland halibut (Reinhardtius hippoglossoides) in ICES Sub-areas I and II, and suggested criteria for legal by-catch of shorter specimens. Working Document, ICES Advisory Committee on Fishery Management (ACFM). Copenhagen, 29 October-6 November 1991.

NEDREAAS, K., P. SANDBERG, A. K. VEIM. MS 1995. Biological and economic implications of a multi-gear fishery for Greenland halibut (Reinhardtius hippoglossoides). ICES C. M. Doc., No. S:5, 25 p.

OLSEN, S. 1959. Mesh selection in herring gill nets. J. Fish. Res. Board. Can., 16: 339-349.

OLSEN, S., and J. TJEMSLAND. 1963. A method of finding an empirical total selection curve for gill nets, describing all means of attachment. Reports on Norwegian Fishery and Marine Investigations, 13(6): 88-94.

ONA, E., and O. R. GODØ. 1990. Fish reactions to trawling noise: the significance for trawl sampling. ICES Rapp. Proc.-Verb., 189: 159-166.

SÆTERSDAL, G. 1963. Selectivity of long lines. In: The Selectivity of Fishing Gear. ICNAF Spec. Publ., 5: 189-192. 